\title{
BOEKBE OORDEELING.
}

\author{
Bijdrage tot de kennis van de sterfle der \\ gemeente Goes, en van den gemiddelden \\ en waarschijnlijken levenshtum harer in- \\ woners, gedurende het dertigjarig tijd- \\ valk van 1830 tot 1859 ; door Dr. K. \\ Broes VAN Dort, te Goes. 1861.
}

Het is voorwaar een opmerkelijk en verblijdend versehijnsel tevens, dat men in de laatste jaren in kleine, zelfs buiten af weinige bekende gemeenten van ons land, mannen ziet opstaan, die met waarlijk prijsselijke vollarding zich beijveren, on de doode cijfers, - of wil men liever, de cijfers der dooden, - uit het stof der gemeente-archieven te doen verrijzen en hun door den invloed van hun onverdroteu ijver, nieuw leven te geven. Door de scherpzinnige en juiste groepering der cijfers hebhen zij dan ook menigwerf waarheden aan den dag gebragt, waarover liet boek der levenden ous tot dusverre in het onzekere heeft gelaten. De doodenregisters hebben in den tegenwoordigen tijd cene gewrigtige beteekenis gekregen voor de levenden; zij leeren ons thans reeds, dat wij door onkunde en ligtzinnigheid zondigen en ons eigen graf delven; zij zulleu, hopen wij, ons eens ook leeren hoe wij zondigen, waarloor zoovele offers vallen vóór den tijd door de natuur bestemd.

De heer van Dort heeft uit zijne nederige en stille stad eene sten doen opgaan, die luide wecrklank znl vinden bij allen, die het wel met ons volk en de menschheid meenen. Hij heeft eene bijdrage tot de Statistiek der sterfte geleverd, welke ten voorbeeld kan strekken aan menigen ambtenaar, die jaar aan jaar zijn leven aan die centoonige taak wijdt. Waarlijk, wij zeggen het hem dan ook na, dat er moed toe behoort om eene statistieke studie te leveren, met hare dorre cijfers en getallen en dat nog wel over een onderwerp, dat tot dusverre nog zoo weinig de algemeene belangstelling gaande maakte, dat voor de meesten niet veel aanlokkelijks heeft en den schrijver evenmin eene billijke waardering van zijnen arbeid belooft, als den uitgever ecn ruim debiet. Maar de bekentenis, die den schrijver aflegt, dat hij dien moed gehad heeft, is den lezer en beoordeelaar 
niet genoeg, zoolang hij daarbij nog niet tevens de bewijzen heeft geleverd, dat hij er ook de bckwambeid en den takt toe bezeten heeft. Want er behoort gewis niet weinig bekwaamheid toe, om aan die los daar heengeworpen cijfers beteekenis en waarde te geven, en vooral niet weinig takt, om ze zoodanig te laten spreken, dat zij ontvankelijke ooren, ook bij de dooven in de Regering zullen vinden, en zoo tastbaar, dat zij bij de blinden onder het wolk ook gevoeld kunnen worden.

$\mathrm{Na}$ de lezing van dien arbeid willen wij gaarne bekennen dat de schrijver zich naar eisch van zijne gewigtige taak heeft gekweten.

Het werkje is in 7 verdeeld, waarvan de 6 eerste vitsluitend aan bijzondere beschouwingen over de sterfte in de gemeente Goes, de laatste aan ,algemeene beschouwingen" is gewijd. Behalve de in den tekst aanwezige tabellen, zijn achterin nog een 5 tal uitvoerige tabellen, tot nadere toelichting van den tekst, geplaatst.

De methode door den Schrijver bij de bearbeiding van zijn onderwerp gevoigd, kwam mij als de meest geschiktste voor op een gebied, waar èn de bouwstoffen niet altijd even volledig en gepast voorhanden zijn, èn, zooals hier, bij een eenigzins gedetailleerd onderzoek, de gegevens zoo gering zijn, dat het veeltijds gewaagd is, daarop eene uitspraak te gronden. Hij bragt nl. de uitkomsten van ziju onderzoek steeds in verband met die door andere statistici op dat gebied hier te lande en elders verkregeu. Die vergelijking was tevens de contrôle voor de juistheid zijner uitspraak en de maatstaf om over den min of meer gunstigen stand van zaken in de plaats van onderzoek te oordeelen. De schrijver is daardoor dan ook tot verrassende, zij het veeltijds ongewensehte uitkonsten geraakt, en dan eens hebben de cijfers treffende overeenkomsten, dan weder in bet oogvallende verschillen en afwijkingen opgeleverd.

$\$ 1$, die cen overzigt van de sterfte, in verband met de bevolking over een tijdrak van 30 (1830/59) jaren levert, doet al dadelijk Goes van eene ongunstige zijde kennen, daar wij er uit outwareu dat hare sterfte genoegzaam gelijk staat met de twee door hare groote sterfte alom gebrandmerkte steden Rottcrlam en Dordrecht. Zij bedraagt daar 1 op 29.3 inwoners.

$\$ 2$ handelt over de verhouding der sterfte tot de geljoorten, zoowel over levende ats levenloos atungegeven kinderen. Ook bier ontwaren wij bedroevende feiten: in de eerste plats eene sterke wisseling van bevolking en in de tweede plaats een in verhouding van de wettige gehoorten, hoog cijfer van levenloos aangegevenen der onechte kiuderen. Schrijper, - en wij met hem, - vinden het verschil, van 36 , belangrijk genoeg, om er eenige oogenblikken bij stil te staan. Het overtreft, zegt $\mathbf{S}$., alles wat ten dien opzigte aangeteekend is geworden omtrent de Statistiek dier sterfte op de kraamzaal van het Binnengasthuis te Ansterdam en van het buitenland (?) bekend is geworden. Terwijl in het eerstgenoemde gesticht de verhouding 
der onecht levend geb. tot de onecht dood geb. stond als 11.83:1, bedroeg die in Goes $6.5: 1$. „Wie huivert niet bij het zien dezer cijfers," roept de S. teregt uit, ,en brengt zich niet onwillekeurig voor den geest het groote aantal geheime misdaden, dat er moet gepleegd worden; al de kommer en ellende, die er moet worden geleden om tot zulke uitkomsten te geraken?" Nog buiveringwekkender is verder de mededeeling, dat de boerenmeiden uit den omtrek van Goes met de middelen tot afdrijving van de vmoht harer zedeloosheid,"op het bedsteê-boord slapen" en zich niet eens de moeite nemen die voor het oog van anderen te verbergen! En toch staan het Goessche „volk" eu de bocrenstand uit den omtrek wijd bekend door hunue streng godsdienstige beginselen, daar in verhouding tot de bevolking nergens in. ons land meer anhlingers van de "afgescheidenen onder het kruis" gevonden worden dan díár en nergens meer strijd gevoerd wordt over het inachtnemen der vormen van de streng regtzinnige kerk. Welligt is er voor den psycholoog zoowel als voor den moralist in deze beide schijnbaar strijdige verschijnselen eenige beteekenis gelegen. De eerste zal welligt eenig verband zoeken tusschen verhoogde geslachtsdrift en ascetisme, de laatste zal beweren dat het trouw inacht nemen van de vormen en gebruiken door het een of ander kerkgenootschap voorgeschreven, nog geen waarborgen voor een reineu levenswandel en opregten godsdienstzin ziju; - maar daar wij hier noch als psycholoog woch als moralist en slechts als prozaïsch recensent optreden, onthouden wij ons van verdere conjecturen en berusten bij de bloote vermelding van het feit.

In $\$ 3$ wordt de sterfte, in verland met den leeftijd en let geslacht besproken, en claar treft ons al dadelijk de buitengewone sterfte der kinderen beneden het jaar; tcgen het einde van het eerste levensjaar bedraagt die toch ruim een derde van do totale sterfte, en gedurende de drie eerste levensjaren bijna de helft der sterfte op elken leeftijd. Opmerkelijk is dit verschil met andere steden van ons rijk, Lecuwarden b. v., waar van de 100 kinderen beneden 't jaar 17 sterven, terwijl in Goes dat antal 38 bedraagt. Welk een outzcttend verschil in cen landje als hat onze. Hoevele schadelijke invloeden mocten bier niet zamengewerkt hebben, om tot zulke ongunstige uitkomsten te leiden. Vele daarvan somt de schrijver dan ook in zijne "algemeene beschouwingen" op.

Wat het vcrschil in levensduur bij de beide geslachten betreft, merkt de S. op, dat de Goessche rrouw ook in een exceptionelen toestand bij hare zusters en andere oorden van ons rijk verkeert. In Goes heeft men namelijk weinig kans on „, een besje van 90 jaren" te worden; een voorregt waarop wij gelooven dat de Goessche dames niet bijster gesteld zullen zijn, bij de meerdere kans die zij daarentegen erlangen on de sneeuwgrenste bereiken. Nogtaus zijn beide geslachten in bun gemiddeld aantal levensjaren weder stiefmoederlijk bedeeld, daar de levensduur der mannen aldaar bijna 4 en 
der vrouwen $3 \frac{1}{2}$ jaren korter is dan in andere steden van Zeeland, en de mannen semiddeld 15 , de vrouwen gemiddeld 13 jaren korter dan in de steden van Drenthe leven!

$\$ 4$, de verhouding van de sterfte der armen tot die der min of meer gegoeden nagaande, is wel bet moeijelijkste deel van den arbeid. De vraag toch : wie is arm en wat is armoede? op zich zelve reeds moeijelijk te beantwoorden, wordt tot eene der moeijelijkste, wanneer daarpan eene oorzaak van ziekte of dood afhankelijk moet gesteld worden. De S. gevoelde dan ook het bezwarende om dit vraagstuk naar eisch op te lossen. De methode voor de levenden door hem ingesligen scheen ons de veiligste. Minder daarentegen die voor de dooden over het 10jarig tijdvak van $1850 / 59$ gevolgd; de maatstaf die de $\mathrm{S}$. tot bepaling van den stand dezer laatsten heeft genomen is te subjectief, en mist genoegzamen grond om den statisticus vertrouwen in te boezemen voor de uitkomsten nit zulk eeu onderzoek verkregen. Welke waarborg toch is het voor ons, om uit de sterfteregisters van 10 jaren, zonder eenigen anderen maatstaf dan de , bekendheid met de personen en hnisgezinnen der overledenen," aan te nemen, ,dat in Goes, gedurende de laatste 10 jaren, bijna 4 armen stierven, tegen ruim 2 min of meer gegoeden, en dat de eersten, gemiddeld, bijna 10 jaren korter leefden dan de laatsten." Hoe onzeker de maatstaf den S. ook toescheen, om hen arm te noemeu, die zelfs onvermogend waren om de negatieve memorie van angifte voor het regt van successie te betalen, scheen zij ons toch toe nog meer objectieve waarde te bezitten, das de thans gekozene. Overigens zou de maatstaf roor de aangeslagen in de Rijks-personele belasting meer overeen zijı gekomen met dieu door den S. over de levenden gekozen: de bedeelden, de niet- en de laagst aangeslagenen in den hoofdelijken gemeente-omslag.

\$5. De sterfte en geboorten, in verband met de jaurgetijden en maanden des jaars beschouwende, levert weder menig treffend bewijs van den invloed, dien bodem en klimaat op de gezondheid en de levensduur van den mensch uitoefenen. Wij vinden hier het reeds meermalen waargenomen feit bevestigd, dat in plaatsen waar mocrasziekten menigvuldig heerschen, de sterfte het grootst is in let najaar (September), het kleinst in den zomer (Junij.)

\$6. De sterfte der verschillende wijken en straten, in Goes, over het tijdvals van 1850 tot 1859 aangevende, is met evenveel zorg bewerkt, ofschoon dit hoofdstuk meer tot het gebied der topographie behoort. Wij volgen den selurijver echter hier ook gaarne in zjjne becijferingen. Op waarlijk vindingrijke en scherpzimnige wijze lost hij hier menige contradictie op. Waterstand, ventilatie, digtheid van bevolking, inrigting van riolen etc. etc. worden hier met de meeste naauwgezetheid als schadclijke momenten van de ongunstige sterfte-verhouding in sommige wijken, straten en zelfs buizen 
nagegaan; de roorbeelden op blz. 54 en 55 , van de Water-en Znsterstraten geleverd, mogen daarvan tot afdoende bewijzen strekken. De $\mathbf{S}$. maakt daarbij de bekcude, maar altijd gewigtige opmerkingen: „dat de sterfteverhouding in die straten het grootst is, waurin het armoedigste gedeelte der bevolking zijn verblijf houdt, en dat in de armoedigste wijken en straten de grootste menschen-productie plaats heeft.

Hiermede is eigenlijk de taak, die de Schrijver op zich heeft genomen, ten einde gebragt.

In de algemeene beschouvingen van $\$ 7$ vat de Schrijver de slotsommen van zijn onderzoek in een 10tal korte stellingen zamen en treedt vervolgens in eenige korte beschouwingen over de vermoedelijk annleidende oorzaken van de ongunstige uitkomsten in de sterfte-verhouding en bevolking van Goes. Hoe los daameer geschreven, hebben die opmerkingen evenwel eene hooge beteekenis en mogen zij tot leerrijke wenken voor regering en burgerij strekken. Daar dit gedeelte voor den leek het meest belangrijke, zeker het boeijendste van het boek is, onthouden wij ons, ook hieruit eenige referaten te leveren. Dringend bevelen wij de lezing daarvan aan, niet alleen aan de Goessenaren, maar aan allen die belang in hume gezondheid en die hunner kinderen stellen: peccatur iztra et extra muros.

Wij gelooven uit de vlugtige beschouwing van dezen arbeid, onze hooge ingenomenheid er mede genoegzaam aangetoond en tevens bewezen te hebben, dat de Schrijver berekend was voor zijne moeitevolle doch niet ondankbare taak. Bij de volvoering van zulk een arbeid moet men in de zelfvoldoening van een nuttig werk verrigt te bebben dank genoeg viuden, zonder dien altijd uit den mond van anderen te moeten verwerven. Moge zijn voorbeeld steeds navolging vinden en door zulke bijdragen eeus de grondslag gelegd worden voor een goede sterftestatistiek van Nederland. Daardoor zullen wij dan tevens in de gelegenheid gesteld worden om tot de oorzaken des doods te geraken, en welligt dat het ons dan gelukken moge, vele schadelijke invloeden af te weren en diizenden kostbare menschenlevens te sparen. Onder de gewigtigste bemoeijingen van de economie sociale behoort toch wel bet behoud van een zeker aantal menschenlevens. Tot dusverre zijn de caders ziekte en armoede in het huishoudboek van den Staat al te rijk vertegenwoordigd, en dat niet zonder groote geldelijke opofferingen voor den Staat en het individu. Zij moeten plaats maken voor hare antipoden: gezondheid en volvaurt. Dan eerst heeft de menschelijke maatschappij haar doel bereikt; dan eerst zal zij tot haren normaalstnat opgevoerd ziju.

A.

Dr. S. S. C. 